\title{
Evaluation of HR System's Worksheet Visualization based on Harvard Model, Life Cycle, and Organization Strategy and Management Type
}

\author{
Yusuke Sato *, Nobuyuki Kobayashi ${ }^{\dagger}$, Seiko Shirasaka *
}

\begin{abstract}
Rapid economic changes have recently been requesting human resource departments in Japanese firms to transform their roles and services. No paper refers a method to map the themes they talk about and to discuss these issues explicitly by using the Harvard Model and Organization Strategy and Management Type. In this paper, we evaluate a worksheet using the Harvard Model and Organization Strategy and Management Type. The worksheet is divided into Visualization Map of HR Systems based on Life Cycle and Organization Strategy and Management Type. We asked employees of Human Resource Departments to use worksheets of "visualization map of HR systems based on life cycle" and "Organization Strategy and Management Type". Then, we evaluated the two points on whether they thought the HR System of their company was appropriate and whether they could write down and explain the HR System to other people. As a result, we confirmed that we achieved the goal of identifying issues of the firm and facilitating discussions with management and HR employees of other companies. In addition, this method could play a role in a training program for people who have a little experience as employees of Human Resource Departments.
\end{abstract}

Keywords: HRM, Harvard Model, Life Cycle, Organization Strategy and Management Type.

\section{Introduction}

In the era of information technology, the motivation and retention of knowledgeable workers in order to gain a winning edge in the market is one of the important challenges for human resource professionals. Human Resource Management (HRM) will be the key area of focus in the 21st century as companies and government organizations put in place strategies to cope up with the economic crisis and recovery. [1] Drucker states that the most important, and indeed truly unique, contribution of management in the 20th century was the fifty-fold increase in the productivity of the manual worker in manufacturing. The most important contribution management needs to make in the 21 st century is similarly to increase the productivity of skilled work and knowledge workers. [2]. Rapid economic changes have recently been requesting human resource departments in Japanese firms to transform their roles and services. [3] In addition, organizations need

\footnotetext{
* Graduate School of System Design and Management, Keio University, Kanagawa, Japan

$\dagger$ The System Design and Management Research Institute of Graduate School of System Design and Management, Keio University, Kanagawa, Japan
} 
to constantly monitor the changes around their internal and external environment to compete and maintain the business interests due to the pressure and brutal competitive conditions of the technetronic age posed by globalization and the Digital Revolution. One of the important approaches can manage this change in the efficient way is Strategic Human Resources Management, which is one of the strategic management processes of human resources within an organization. [4] Still most organizations gave employees little control over their careers, preferring to make placement and promotion decisions without consultation. [5]

In a questionnaire survey conducted by Miwa, the more companies utilize HRM to emphasize individual achievements, utilize the external labor market, and to invest human resources development, the more knowledge workers continue to work for these companies. [6] Abdullah describes that there is a positive correlation between effective HRM practices and financial performance. [7] Improving the process of HR Systems by using HRM practices is a factor to increase competitive advantages of companies. Boxall et al. divide competitive advantages into "Human Capital Advantage" and "Human Process Advantage". He also explains that "Human Process Advantage" is more difficult for other companies to imitate. [8] Therefore, it is important to design and operate HR Systems from a strategic point of view, to increase the outcome of HRM and to build the core competence of an organization. [3]

It is ambiguous as to who decides the HR Strategy, HR Management Process, and HR System. [9] Employees of Human Resource Departments are often confused as to what area they discuss as they do not have enough viewpoints. [9] In addition, it is necessary to design appropriate HR Systems based on HR Management such as controlled or autonomous types. [9] However, no paper refers to a method for mapping the theme they talk about and to discuss these issues explicitly by using the Harvard Model and Organization Strategy and Management Type in this study. For solving the three issues described in previous studies, the purpose of this study thus is to propose a method to map the theme they talk about and to discuss the issues explicitly by using the Harvard Model and Organization Strategy and Management Type. In addition, we evaluate the two points of whether they thought the HR System of their company was appropriate and whether they could write down and explain the HR System to other people.

Next, we explain the novelty of this study as follows. Figen et al. have proposed the method of the HRM business process model to evolute it by using IDEF0. [10] This study differs from the previous study [10] in that it does not fit the strategy and management type of companies. Itakura [11] introduced the conception of creative self-managing organizations in modern times based on Mintzberg [12].Therefore, the previous study [11] introduces a viewpoint for thinking about strategy formation, however the previous study is not a study that integrates the viewpoint of management. This study suggested the worksheet combine the viewpoint of strategy formation and management type, which differ the previous study [11]. Liu [13], Oso [14] use the viewpoint of Harvard Model suggested by Beer et al. [5] aimed at implementing human resource management. These previous studies [13] [14] are not studies that focus on visualizing the map of HR Systems. Iida, Nicholson, and Ayubu referred especially recruiting area. [15] [16] [17] However, our study captures the whole of human resource management. Therefore, the novelty of this study is to evaluate a worksheet to visualize HR Systems based on Organization Strategy and Management Type. We verify and validate a worksheet to map the theme they talk about and to discuss the issues explicitly by using the Harvard Model.

In the following, first, in Chapter 2, we outline the Human Resource Management theory, especially the Harvard Model. In addition, we explain the Visualization Map of HR Systems based 
on Life Cycle. Then, in Chapter 3, we refer Organization Strategy and Management Type. We describe the evaluation method and the evaluation results in Chapter 4. Finally, we state discussion to review the results of evaluation in Chapter 5 and we summarize what we indicated and explain the direction of future research as a conclusion in Chapter 6.

\section{Literature Review}

\section{A. Definition of HRM (Human Resource Management)}

Beer et al. define HRM as "all management decisions and actions that affect the nature of the relationship between the organization and employees-its human resources." [5] In this paper, we use Beer et al.'s definition as we created the method based on the Harvard Model proposed by him.

\section{B. Features of the Harvard Model}

Beer et al. offer the "Map of the HRM Theory" for diagnosing not only the impact of management decisions on the human resources of the firm, but also whether or not the policies that guide those decisions continue to make sense and what changes might be considered in them. [5] Beer et al. show the analytical approach in Figure 1 which is a broad causal mapping of the determinants and consequences of HRM Policy Choices.

C. Features of the Harvard Model

Sato et al. suggested a matrix using the three axes of target employee, Human Resource Flow, and Life Cycle Stage. [18]

As mentioned in previous sections, no paper referring to Human Resource Flow shows how to construct and operate HRM Policy Choices in the Harvard Model which includes Human Resource Flow, Work System, Reward System, and Employment Influence by using the concept of Life Cycle Stage. [18] Therefore, this paper uses HRM Policy Choices instead of Human Resource Flow in Figure 2.

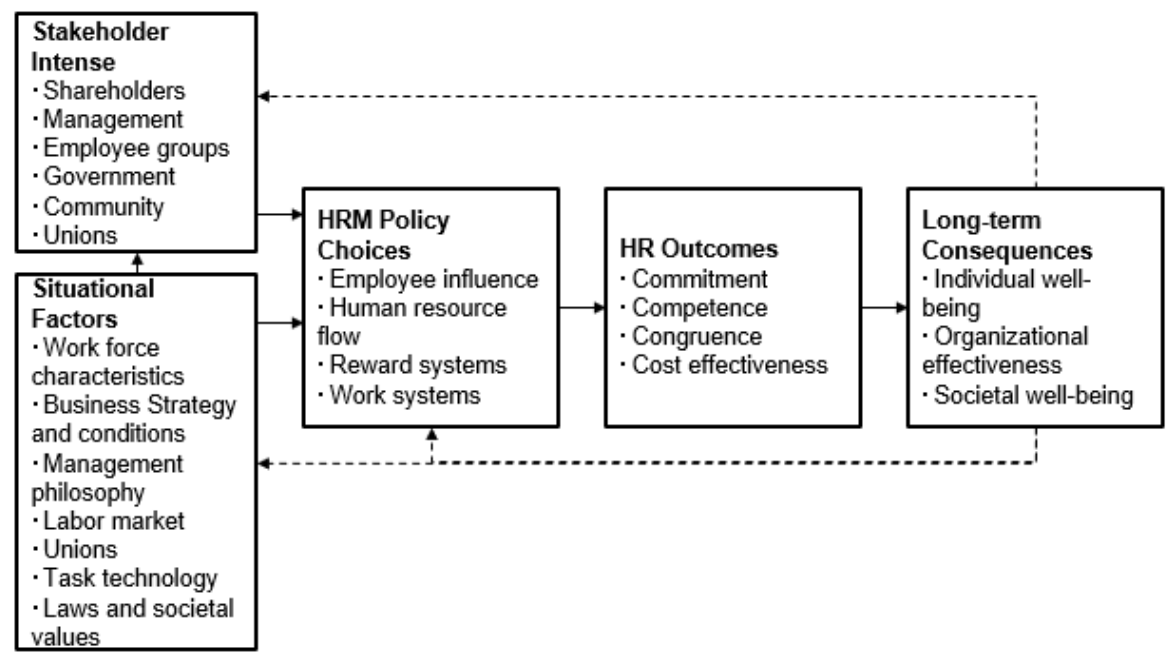

Figure 1: Map of the HRM Theory [5]. 


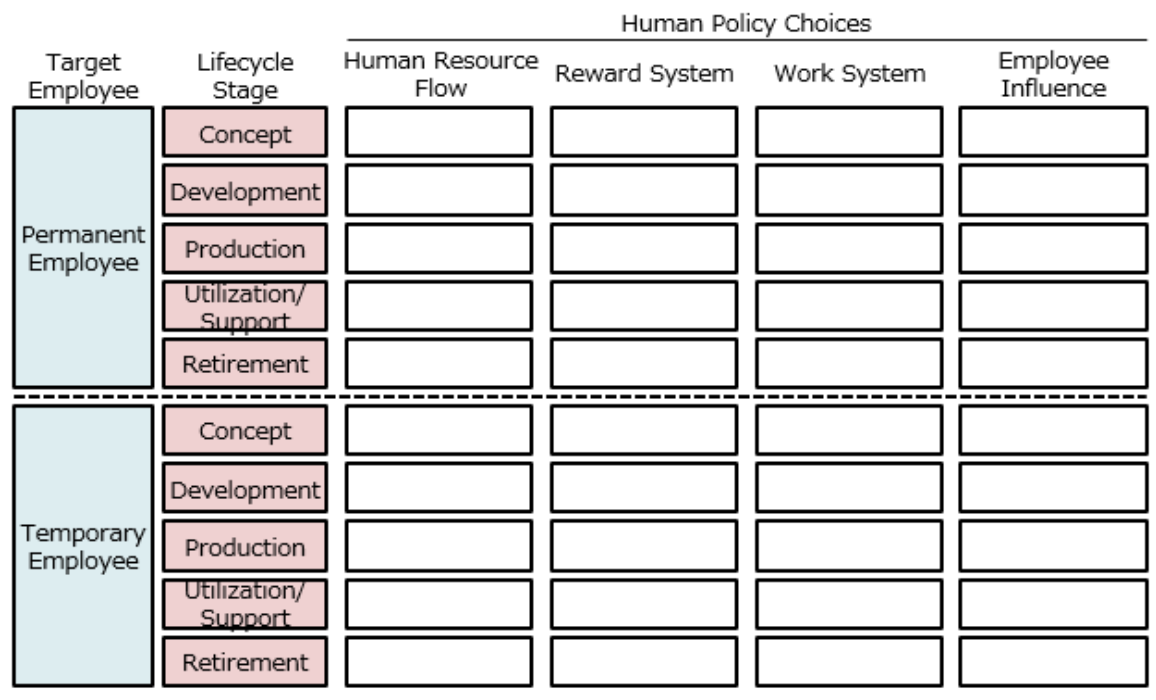

Figure 2: Visualization Map of HR System based on Life Cycle [18].

\section{Map of the Harvard Model with Three points of view}

Sato et al. added a feedback process to Human Resource Policy Choices from HR Outcomes. [19] In this paper, we focus on "1. HRM Policy Choices" in Figure 3. After making four HR Systems within HRM Policy Choices, we will be able to check "2. Verification of HR Outcomes" as well as "3. Feedback to HRM Policy Choices from HR Outcomes".

\section{E. Creative and Autonomous Organizations}

Itakura suggested the concept of "creative autonomous organization". [11] He stated that the need for a creative and autonomous organization has emerged in modern companies, and its functions are a combination of "creative aspect" and "autonomous aspect". The autonomous aspect has long been taken in the context of companies adapting to environmental changes.

In such a case, the organization itself is under self-control with a large degree of delegation of authority, and the "Plan (plan) — Execution (do) - Control (see)" step is carried out under self-control within the organization. They will also evaluate any plans and results selected. The centralized command system made it difficult to respond effectively to various issues, and the need for on-site coordination arose. [11] Therefore, in this study, we define a centralized management system in which the field faithfully follows the direction of the top of an organization. We also define a decentralized management system in which the organization responds to diverse issues on the ground. 


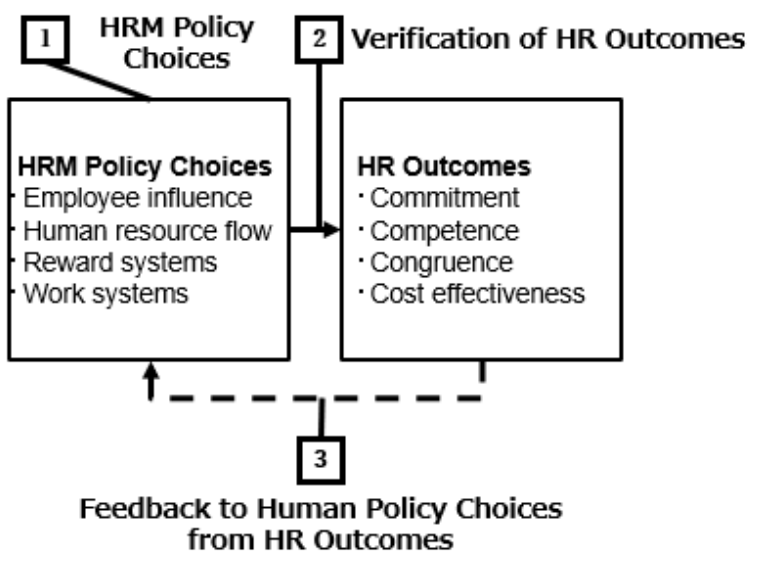

Figure 3: Map of the Harvard Model with Three points of view [19]

\section{A Proposal of HR System's Worksheet Visualization based on Harvard Model, Life Cycle, and Organization Strategy and Management Type}

A. Organization Strategy and Management Type

In this paper, we propose a method to map the theme they talk about and to discuss the issues explicitly by using the Harvard Model and Organization Strategy and Management Type. The method is divided into Visualization Map of HR Systems based on Life Cycle and Organization Strategy and Management Type. As we mentioned Visualization Map of HR Systems based on Life Cycle, we explain Organization Strategy and Management Type in this section.

First, we quote Strategy Formation which is composed of Deliberate and Emergent as the vertical axis. [12] Deliberate Strategy is realized as people intended. Emergent Strategy is realized in the absence of intentions. Second, we define the management type, Centralization or Decentralization, as the horizontal axis. Finally, we call this matrix Organization Strategy and Management Type and name the four boxes in Figure 4.

B. Explanation of each segment in Organization Strategy and Management Type

(1) Deliberate Strategy and Centralization Management Type (DSCM)

In this segment, the strategy of a company is decided by the management team. The strategy is executed through centralization. When people of the Human Resources Department construct their HR System, it is important how their employees act in accordance with the strategy. In addition, people of the Human Resources Department need to confirm whether a HR System is compatible with their own Strategy. It is effective, for example, in heavy-duty and large-sized industries as well as highly confidential businesses because this organization type consolidates the authority in the management team. However, when the strategy is wrong, there is a risk of suffering fatal damage. Employees cannot raise their voices in dissatisfaction and retire as a result of strong centralization. 


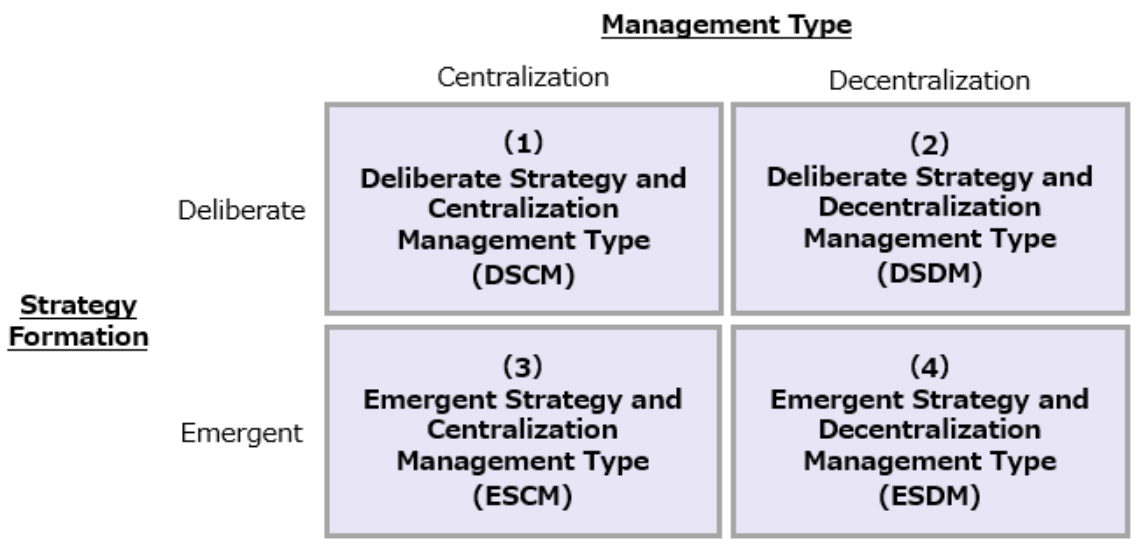

Figure 4: Organization Strategy and Management Type.

(2) Deliberate Strategy and Decentralization Management Type (DSDM)

In this segment, although corporate strategy is decided by the management team, the employees can execute their work autonomously. Therefore, it is important to design ways to promote collaboration among employees after the management team announces the strategy. The employees of the Human Resources Department need to pay attention to the delegation of authority and foster a collaborative culture in their organizations. This organization type is particularly effective in businesses that have a high uncertainty in their industry and speed because management teams indicate guidelines and employees can work based on their decision. On the other hand, there is the disadvantage of suffering fatal damage when the strategy is wrong and a risk that the autonomy of the employees increases the management cost.

\section{(3) Emergent Strategy and Centralization Management Type (ESCM)}

In this segment, a corporate strategy is created emergently by their employees and it is executed centrally. For this, it is important how to develop the strategy emergently, how to decide who will manage and pursue the execution of the formulated strategy, and how to raise employee's commitment. In other words, the balance between "autonomy" and "centralization" is the key. This organization type is good for large enterprises in need of innovation and startup companies in the stage of providing a new business to the world. However, it takes time to decide strategy. If the management shift unconsciously from ESCM to DSCM type, the employees may hate the shrinking of their business and authority and leave the firms. Transition of organization type can generate risks that can cause employees to retire as they dislike the new organization types.

\section{(4) Emergent Strategy and Decentralization Management Type (ESDM)}

In this segment, a strategy of a company is emergently created, and the employees execute it autonomously. We call this type of organization "DAO" (Decentralized Autonomous Organization). It is the most difficult to design rules to manage this organization. It is important to promote commitment while guaranteeing the autonomy of employees. This organization type is highly effective for business situations where the uncertainty is high and a number of new businesses need to be launched and deployed quickly. Otherwise, there is a danger of being broken down because there is no policy or management theory. 
C. Worksheet of Visualizing HR Systems based on Organization Strategy and Management Type

We created a worksheet to make it easy to use the "Visualization Map of HR Systems based on Life Cycle" and "Organization Strategy and Management Type". In the worksheet, we set several frames in order to define the "Organization Strategy and Management Type" and the scope of the HR System. Next, it is possible to clearly show which area we are discussing by writing out the HR System in detail for each Life Cycle Stage. We show the worksheet in Figure 5.

\begin{tabular}{|l|l|}
\hline Name & \\
\hline 1. HR System & Company / Department / Individual \\
\hline 2. Object & Permanent / Temporary \\
\hline 3. Employee Type \\
\hline $\begin{array}{l}\text { 4. Organization } \\
\text { Strategy and } \\
\text { Management Type }\end{array}$ & DSCM / DSDM / ESCM / ESDM \\
\hline
\end{tabular}

\begin{tabular}{|c|c|c|c|c|c|}
\hline \multirow{2}{*}{\multicolumn{2}{|c|}{$\begin{array}{c}\text { The Matrix } \\
\text { to Create HR System }\end{array}$}} & \multicolumn{4}{|c|}{ HR Policy Choices } \\
\hline & & \multirow[t]{2}{*}{ Human Resource Flow } & \multirow[t]{2}{*}{ Reward System } & \multirow[t]{2}{*}{ Work System } & \multirow[t]{2}{*}{ Employee Influence } \\
\hline \multirow{2}{*}{$\begin{array}{l}\mathrm{L} \\
\mathrm{i} \\
\mathrm{f} \\
\mathrm{e}\end{array}$} & Concept & & & & \\
\hline & Development & & & & \\
\hline $\begin{array}{l}y \\
c \\
1\end{array}$ & Production & & & & \\
\hline \multirow{2}{*}{$\begin{array}{l}S \\
\mathrm{t} \\
\mathrm{a} \\
\mathrm{g} \\
\mathrm{e}\end{array}$} & $\begin{array}{l}\text { Utilization / } \\
\text { Support }\end{array}$ & & & & \\
\hline & Retirement & & & & \\
\hline
\end{tabular}

Figure 5: Worksheet of Visualizing HR System based on Organization Strategy and Management Type.

\section{Evaluation for HR System's Worksheet Visualization based on Harvard Model, Life Cycle, and Organization Strategy and Management Type}

\section{A. Verification Procedure and Content}

We asked 12 employees of Human Resource Departments of small or major IT companies and financial companies to use the worksheet "Visualization map of HR systems based on life cycle" and "Organization Strategy and Management Type". Then, we evaluated the two points on whether they thought the HR System of their company was appropriate and whether they could write down and explain the HR System to other people. When they finished, I let them review 
HR Systems through discussions with other members and finally answer the questionnaire. We analyzed the results of the questionnaire and worksheet and then conducted validation. We show this evaluation procedure and content in Figure 6.

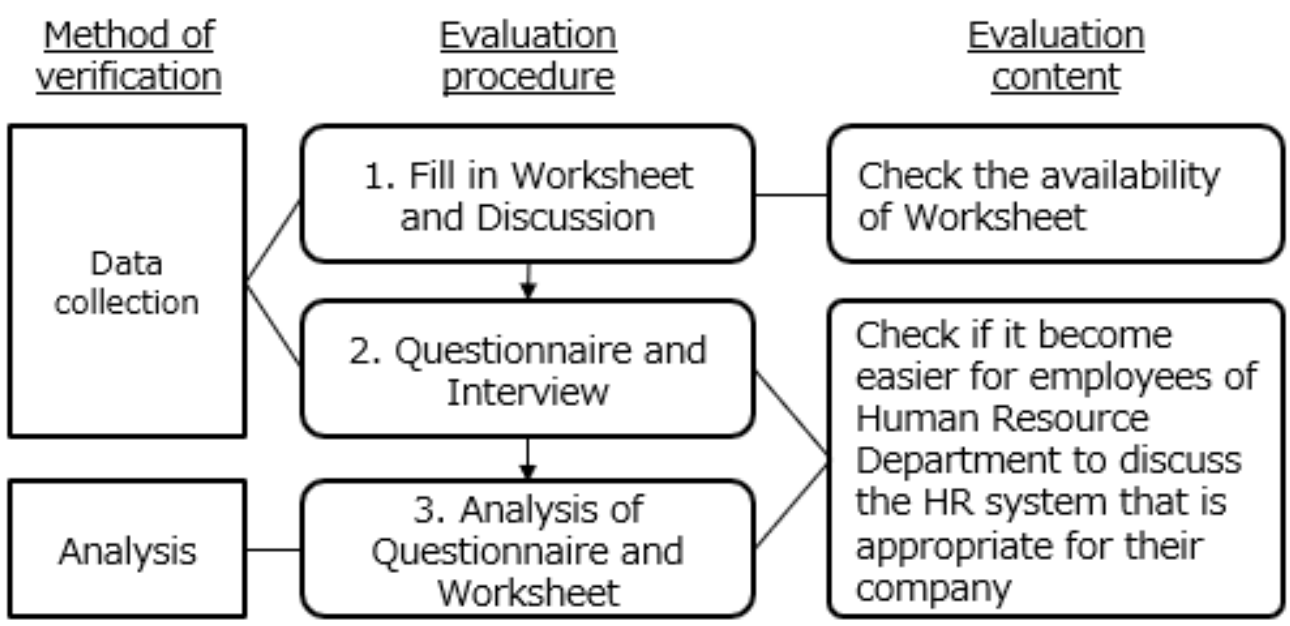

Figure 6: Evaluation Procedure and Content.

B. Evaluation Results about Validation

We show the results of the evaluation results about validation in Table 1. From the result of No. 1, more than $90 \%$ of the people were able to visualize what they discussed and what they wanted to convey by using this method. In addition, it was also confirmed from the result of No. 2 that more than $90 \%$ of the personnel could make discussion easier by using the worksheet. Finally, we checked the validity of the result of No.3 that $75 \%$ of the people can easily discuss the appropriate HR system based on their Organization Strategy and Management Type. However, only 7 out of 12 people who could complete the matrix comprehensively; more than $90 \%$ which was 18 boxes out of 20 boxes on the worksheet.

Table 1: The evaluation result of 12 human resource department employees about validation.

\begin{tabular}{|c|c|c|c|c|}
\hline Evaluation method & No. & Evaluation item & Evaluation criteria & Evaluation results \\
\hline \multirow{3}{*}{ Questionnaire } & 1 & $\begin{array}{l}\text { Whether the worksheet make } \\
\text { it possible to visualize what } \\
\text { you are discussing and what } \\
\text { you want to convey. }\end{array}$ & $\begin{array}{l}\text { Majority of positive } \\
\text { responses }\end{array}$ & $\begin{array}{c}\text { Effectiveness } \\
(91.6 \%)\end{array}$ \\
\hline & 2 & $\begin{array}{l}\text { Whether the worksheet make } \\
\text { it easy to argue with other } \\
\text { people. }\end{array}$ & $\begin{array}{l}\text { Majority of positive } \\
\text { responses }\end{array}$ & $\begin{array}{c}\text { Effectiveness } \\
(91.6 \%)\end{array}$ \\
\hline & 3 & $\begin{array}{l}\text { Whether the worksheet make } \\
\text { it easy for employees of } \\
\text { human resource department to } \\
\text { discuss their appropriate HR } \\
\text { system. }\end{array}$ & $\begin{array}{l}\text { Majority of positive } \\
\text { responses }\end{array}$ & $\begin{array}{c}\text { Effectiveness } \\
(75.0 \%)\end{array}$ \\
\hline Worksheet & 4 & $\begin{array}{l}\text { Whether the employees of } \\
\text { human resource department } \\
\text { comprehensively considered } \\
\text { the appropriate HR system of } \\
\text { their company? }\end{array}$ & Fill in the box over $90 \%$ & $\begin{array}{r}7 \text { people out of } \\
12 \text { people }\end{array}$ \\
\hline
\end{tabular}




\section{Evaluation Results for Comprehensibility, Availability, Effectiveness}

We show the evaluation results for Comprehensibility, Availability, Effectiveness in Table 2. From the result of No. 5, 66.7\% of the people stated that the framework structure was easy to understand. In addition, it was also confirmed from the result of No. 6, No. 7, and No.8 HR employees were able to understand the concepts of Organization Strategy and Management Type, HRM Policy Choices, and Life-Cycle Stage. From the result of No. 6, all of the people mentioned that they understood the concepts of Organization Strategy and Management Type. From the result of No. 7, 75.0\% of the people stated that they understood HRM Policy Choices. From the result of No. 8, 91.7\% of the people stated that they understood the concept of Life-Cycle Stage. Next, from the result of No. 9, we confirmed the availability of the worksheet as $66.7 \%$ of people answered that the framework worksheet was easy to organize. Finally, we checked the effectiveness of the worksheet from the results of No.10 to No. 14. From the result of No. 10, 75\% of the people stated that the framework has made it easier for them to organize their thoughts and communicate their requests. From the result of No. 11, 75\% of the people answered that they were more comfortable with their HR system. From the result of No. 12, 75\% of the people mentioned that they have gained a better understanding of HR systems of other companies. From the result of No. $13,66.7 \%$ of the people mentioned that they thought it would be easier to work with the president. From the result of No. 14, 66.7\% of the people stated that they found it easier to work with other HR professionals. However, the result of No. 15 and 16 implied that there were some improvements. From the result of No. 15, $41.7 \%$ of the people mentioned that they thought it would be easier to work with their employees. In addition, from the result of No. 16, only $33.3 \%$ of the people stated that they thought employees could communicate their needs to management and human resource departments. For reference, we show the actual completed worksheet in Figure 7. The subject could write specific items of the entire lifecycle from concept to retirement because he had HR experience more than 10 years. The lifecycle of the worksheet allows him to clearly extract what needs to be done. For example, we confirm the effectiveness of the proposed worksheet by the result writing "Fit for the company" in Figure 7. The reason is that he was able to verbalize his goals in the cell of concept, which he had not been well do. We confirm the effectiveness of the proposed worksheet by the result writing "Training of human resources to contribute to the company" in Figure 7. The reason is that he was able to think concretely about how to achieve the goal of "Fit for the Company" in the cell of concept. However, he did not describe Employee Influence since there was no specific information about it. 
Table 2: The evaluation result of 12 human resource department employees about Comprehensibility, Availability, and Effectiveness.

\begin{tabular}{|c|c|c|c|c|}
\hline Evaluation method & No. & Evaluation item & Evaluation criteria & Evaluation results \\
\hline \multirow{4}{*}{ Comprehensibility } & 5 & $\begin{array}{l}\text { Is the framework structure } \\
\text { easy to understand? }\end{array}$ & $\begin{array}{l}\text { Majority of positive } \\
\text { responses }\end{array}$ & $\begin{array}{c}\text { Effectiveness } \\
(66.7 \%)\end{array}$ \\
\hline & 6 & $\begin{array}{l}\text { Do you understand the } \\
\text { concepts of Organization } \\
\text { Strategy and Management } \\
\text { Type }\end{array}$ & $\begin{array}{l}\text { Majority of positive } \\
\text { responses }\end{array}$ & $\begin{array}{l}\text { Effectiveness } \\
\quad(100.0 \%)\end{array}$ \\
\hline & 7 & $\begin{array}{l}\text { Do you understand HRM Policy } \\
\text { Choices? }\end{array}$ & $\begin{array}{l}\text { Majority of positive } \\
\text { responses }\end{array}$ & $\begin{array}{c}\text { Effectiveness } \\
(75.0 \%)\end{array}$ \\
\hline & 8 & $\begin{array}{l}\text { Do you understand the } \\
\text { concept of Life-Cycle Stage? }\end{array}$ & $\begin{array}{l}\text { Majority of positive } \\
\text { responses }\end{array}$ & $\begin{array}{c}\text { Effectiveness } \\
(91.7 \%)\end{array}$ \\
\hline Availability & 9 & $\begin{array}{l}\text { Is the framework worksheet } \\
\text { easy to organize? }\end{array}$ & $\begin{array}{l}\text { Majority of positive } \\
\text { responses }\end{array}$ & $\begin{array}{c}\text { Effectiveness } \\
(66.7 \%)\end{array}$ \\
\hline \multirow{7}{*}{ Effectiveness } & 10 & $\begin{array}{l}\text { Has the framework made it } \\
\text { easier for you to organize your } \\
\text { thoughts and communicate } \\
\text { your requests? }\end{array}$ & $\begin{array}{l}\text { Majority of positive } \\
\text { responses }\end{array}$ & $\begin{array}{c}\text { Effectiveness } \\
(75.0 \%)\end{array}$ \\
\hline & 11 & $\begin{array}{l}\text { Are you more comfortable with } \\
\text { your HR system? }\end{array}$ & $\begin{array}{l}\text { Majority of positive } \\
\text { responses }\end{array}$ & $\begin{array}{c}\text { Effectiveness } \\
\quad(75.0 \%)\end{array}$ \\
\hline & 12 & $\begin{array}{l}\text { Have you gained a better } \\
\text { understanding of the HR } \\
\text { system of other companies? }\end{array}$ & $\begin{array}{l}\text { Majority of positive } \\
\text { responses }\end{array}$ & $\begin{array}{c}\text { Effectiveness } \\
(75.0 \%)\end{array}$ \\
\hline & 13 & $\begin{array}{l}\text { Do you think it will be easier to } \\
\text { work with the president? }\end{array}$ & $\begin{array}{l}\text { Majority of positive } \\
\text { responses }\end{array}$ & $\begin{array}{c}\text { Effectiveness } \\
(66.7 \%)\end{array}$ \\
\hline & 14 & $\begin{array}{l}\text { Do you find it easier to work } \\
\text { with other HR professionals? }\end{array}$ & $\begin{array}{l}\text { Majority of positive } \\
\text { responses }\end{array}$ & $\begin{array}{c}\text { Effectiveness } \\
(83.3 \%)\end{array}$ \\
\hline & 15 & $\begin{array}{l}\text { Do you think it will be easier to } \\
\text { work with employees? }\end{array}$ & $\begin{array}{l}\text { Majority of positive } \\
\text { responses }\end{array}$ & $\begin{array}{l}\text { Not Effectiveness } \\
(41.7 \%)\end{array}$ \\
\hline & 16 & $\begin{array}{l}\text { Do you think employees can } \\
\text { communicate their needs to } \\
\text { management and human } \\
\text { resource department? }\end{array}$ & $\begin{array}{l}\text { Majority of positive } \\
\text { responses }\end{array}$ & $\begin{array}{l}\text { Not Effectiveness } \\
(33.3 \%)\end{array}$ \\
\hline
\end{tabular}




\begin{tabular}{|l|l|}
\hline Name & \\
\hline 1. HR System & Tr Company \\
\hline 2. Object & Company \\
\hline 3. Employee Type & Permanent \\
\hline $\begin{array}{l}\text { 4. Organization } \\
\text { Strategy and } \\
\text { Management Type }\end{array}$ & DSDM \\
\hline
\end{tabular}

\begin{tabular}{|c|c|c|c|c|c|}
\hline \multirow{2}{*}{\multicolumn{2}{|c|}{$\begin{array}{l}\text { The Matrix } \\
\text { to Create HR System }\end{array}$}} & \multicolumn{4}{|c|}{ HR. Pollicy Choices } \\
\hline & & Human Resource Flow & Reward System & Work System & Employee Influence \\
\hline \multirow{2}{*}{$\begin{array}{l}\mathrm{L} \\
\mathrm{i} \\
\mathrm{f} \\
e\end{array}$} & Concept & Fit for the Company & $\begin{array}{l}\text { Mission grade to match the } \\
\text { size of the job }\end{array}$ & $\begin{array}{l}\text { Design of big incentives for } \\
\text { the work you pive }\end{array}$ & - \\
\hline & Development & $\begin{array}{l}\text { Training of human resources } \\
\text { to contribute to the company }\end{array}$ & $\begin{array}{l}\text { The Importance of lob Size } \\
\text { Design }\end{array}$ & Longer term MBO & - \\
\hline $\begin{array}{l}y \\
y \\
\text { c } \\
1 \\
0\end{array}$ & Production & $\begin{array}{l}\text { Hiring and on-the-job } \\
\text { training with an emphasis on } \\
\text { fit to the compory }\end{array}$ & $\begin{array}{l}\text { Inb-specilic grading for } \\
\text { individuals }\end{array}$ & $\begin{array}{l}\text { Selting goves that cascade } \\
\text { from upstream gowis }\end{array}$ & - \\
\hline \multirow{2}{*}{$\begin{array}{l}\mathrm{s} \\
\mathrm{t} \\
\mathrm{a} \\
\mathrm{g} \\
\mathrm{e}\end{array}$} & $\begin{array}{l}\text { Utilization / } \\
\text { Support }\end{array}$ & $\begin{array}{l}\text { Fieid-Centered Human } \\
\text { Resource Management }\end{array}$ & $\begin{array}{l}\text { Points-based certification } \\
\text { point management by } \\
\text { department }\end{array}$ & $\begin{array}{l}\text { Field-Centered Hurnan- } \\
\text { Resource Managernent. }\end{array}$ & - \\
\hline & Retirement & $\begin{array}{l}\text { Human resource } \\
\text { management for expansion } \\
\text { into new areas }\end{array}$ & $\begin{array}{l}\text { Managing when complebely } \\
\text { different duties arise }\end{array}$ & $\begin{array}{l}\text { Managing when we can no } \\
\text { langer hire people }\end{array}$ & - \\
\hline
\end{tabular}

Figure 7: Worksheet filled out by a person who belong to human resource department of an IT company

\section{Conclusions}

\section{A. Summary}

In this paper, we evaluated a worksheet by using the Harvard Model and Organization Strategy and Management Type. The method is divided into Visualization Map of HR Systems based on Life Cycle and Organization Strategy and Management Type. We asked employees of Human Resource Departments to use a worksheet of "Visualization map of HR systems based on life cycle" and "Organization Strategy and Management Type". Then, we evaluated the two points on whether they thought the HR System of their company was appropriate and whether they could write down and explain the HR System to other people. As a result, we confirmed that we achieved the goal of identifying issues of the firm and facilitating discussion with management and HR employees of other companies. In addition, this method can play a role in a training program for people who have little experience as employees of Human Resource Departments.

\section{B. Evolution of Future Research}

We discovered some challenges in the future through this study. First, we need to suggest a method to measure the Maturity of HR Systems. When we create this, we will be able to find issues of HR Systems easily. Second, we should find the issues in detail by using Systems 
Engineering. We can identify problems easily when we use Systems Engineering as it is a comprehensive standard model. Third, further research is needed on how to build an appropriate HR System using the Harvard Model and Systems Engineering. No paper describes a method to create a HR System to combine the Harvard Model and Systems Engineering based on Organization Strategy and Management Type. Fourth, If the lack of personnel ability causes the low maturity of the HR System, we need to suggest an effective training program. Fifth, we tested people who work in the HR department in this study. However, it is not clear whether the study can be applied to people who are not belong to human resource department. Therefore, it is necessary to define the subjects to be compared in detail and conduct a statistical analysis in the future. Finally, there are also some problems to solve from the evaluation result in Table 2. Future research should improve the worksheet to make it easier to work with employees. In addition, future research needs to revise the method so that employees can communicate their needs to management and human resource departments.

\section{References}

[1] M. Ravisankar, K. Sakthivendan., "Human resource management practices in Indian IT industry-an overview", International Journal of Exclusive Management Research, Vol. 3, Issue 1, 2013, pp.1-14.

[2] Drucker., "Knowledge-Worker Productivity:The Biggest Challenge", Carifornia Management Review, Winter 1999 vol.41, No.2, 1999, pp.79-94.

[3] Yasunaki Kido, Tomohiro Sudoh, "Toward a New Era of HR Departments “, Sanno University bulletin, Vol. 27, Issue 1, 2006, pp. 21-46.

[4] İlhami Kaygusuz, Tahir Akgemci, Abdullah Yilmaz., "The impact of HRIS usage on organizational efficiency and employee performance", International Journal of Business and Management, Vol. IV, No. 4, 2016, pp.14-52.

[5] Michael Beer, Bert Spector, Paul R. Lawrence, D.Quinn Mills, and Richard E. Walton, "Managing Human Assets, Simon and Schuster", 1984.

[6] Takumi Miwa., "Human Resource Management of Knowledge Workers", Chuokeizai-Sha Holdings, Inc, 2015.

[7] Abdullah Attia Al-Zahrani, Ahmad Aref Almazari, "The Impact of Affective Human Resources Management Practices on the Financial Performance of the Saudi Banks", Review of Integrative Business and Economics Research, Vol. 3, Issue 1, 2014, pp. 346-356.

[8] Peter Boxall, Mike Steeneveld, "Human resource strategy and competitive advantage: A longitudinal study of engineering consultancies", Journal_of_Management_Studies, Vol.36, Issue 4, 1999, pp. 443-463.

[9] Yusuke Sato, Nobuyuki Kobayashi, Seiko Shirasaka, "A Proposal of HR System's Visualization Based on Harvard Model, Life Cycle, and Organization Strategy and Management Type." 2019 8th International Congress on Advanced Applied Informatics (IIAI-AAI). IEEE, 2019. 
[10] Figen Cakar, Umit S. Bititci, Jillian MacBryde., "A business process approach to human resource management", Business Process Management Journal, Vol. 9 No.2, 2003, pp.190207.

[11] Fumihiko Itakura, "A Study of Creative Self-managing Organizations in Modern Times" The bulletin of Jissen Women's Junior College Vol.31, 2010, pp. 1-12.

[12] Mintzberg, Henry, Alexandra McHugh, "Strategy formation in an adhocracy" Administrative science quarterly, Vol. 30, No. 2, 1985, pp. 160-197.

[13] Liu Wei., "The Possibility of implementing Strategic Human Resource Planning in Japaneseaffiliated companies in China", Doctoral dissertation, Fukuoka University, 2014.

[14] Nobuyoshi Oso., "SENRYAKUTEKI JINTEKISHIGENKANRINO TOUGOUAPURO$\mathrm{CHI}$ (Integrated approach of strategic human resource management theory)", University of Hyogo, 2015.

[15] Iida Pukkila., "Recruiting skilled orderlies for health care organization", Bachelor's Thesis of Degree Programme in International Business, 2012, 88 pages, 2 pages of appendices.

[16] Nicholson, Wallace C., and Sean A. Gibbs. Recruiting the cyber leader: an evaluation of the human resource model used for recruiting the Army's" Cyber Operations Officer". Diss. Monterey, California: Naval Postgraduate School, 2017.

[17] Ayubu Japheth Chenelo., "Teachers' recruitment and retention in Tanzania", masters dissertation, University of Dar es Salaam, 2011.

[18] Yusuke Sato, Nobuyuki Kobayashi, Seiko Shirasaka, "An Analysis of Human Resource Management for Knowledge Workers -Using Three Axes of Target Employee, Lifecycle Stage, and Human Resource Flow- ", Review of Integrative Business and Economics Research, Vol. 9, Issue 1, 2019, pp. 140-156.

[19] Yusuke Sato, Nobuyuki Kobayashi, Seiko Shirasaka, "Deriving Challenges through Clarification of Areas to Strengthen the HR System-Using A Matrix with the Three Axes of Target Employee, Life Cycle Stage, and HRM Policy Choices" International Journal of Japan Association for Management Systems", Vol. 11 No. 1, 2019, pp. 91-101. 